\title{
1 Historical eruptions of Lautaro volcano and their impacts on lacustrine ecosystems
}

\section{2 in southern Argentina}

4

5

6

7

This document is the accepted manuscript version of the following article: 
39 Key words: Patagonia, northern Austral Volcanic Zone, ${ }^{210} \mathrm{~Pb}$ dating, Diatoms, Geochemistry, Stable 40 isotopes 
Lacustrine sequences were obtained from Laguna Verde and Laguna Gemelas Este, two small lakes located east of the southern Patagonian Ice Field and close to the village of El Chaltén in Argentinian Patagonia. Four tephra layers were identified in each of these short sedimentary sequences and characterised using individual glass-shard tephra chemistry to determine provenance. In order to understand the impact of the tephra deposits on lake ecosystems, bulk sediment geochemistry and diatom assemblages were analysed. Age-depth models for the cores were established by radiometric dating using ${ }^{137} \mathrm{Cs}$ and ${ }^{210} \mathrm{~Pb}$ measurements.

The tephra deposits in Laguna Gemelas Este were dated to AD 1986-1998, 1943-1968, 1927-1955 and 1849-1892, and the tephra deposits in Laguna Verde were dated AD 1940-1970, 1888-1934, 1871-1920, and 1536-1669 (the last age based on extrapolation). All tephras had a similar geochemical composition and originated from volcanoes in the northern Austral Volcanic Zone. The tephra units were attributed to known historical events and, most likely all but one, were from Lautaro volcano $\left(49^{\circ} 01^{\prime} \mathrm{S} ; 73^{\circ} 33^{\prime} \mathrm{W}\right)$. The age of the youngest tephra (AD 1986-1998) from Laguna Gemelas Este points to a possible Viedma volcano (49 $\left.22^{\prime} \mathrm{S} ; 73^{\circ} 19^{\prime} \mathrm{W}\right)$ source.

The volcanic eruptions had a larger impact on the Laguna Verde lake ecosystem than on Laguna Gemelas Este, as evidenced by repeated shifts in nitrogen isotopes and diatom communities during tephra deposition. This is explained by disturbances of the nitrogen cycle in the lake due to impacts on lacustrine primary production. Primary producers may have been affected by increased water turbidity caused by the ash fall and subsequently less nitrogen was utilized. Diatom assemblages in Laguna Verde showed markedly decreasing numbers of planktonic/tychoplanktonic taxa in favour of epiphytic/benthic diatom taxa when tephra was deposited. This contrasts with Laguna Gemelas Este, in which epiphytic/benthic diatom species were generally more abundant and the decrease of planktonic/tychoplanktonic taxa abundances were not so strictly linked to tephra layers as for Laguna Verde. At Laguna Gemelas Este, the flatter relief, higher wind-fetch and/or drier climate may be the reason for generally higher ecosystem variability resulting in seemingly less environmental response than in Laguna Verde to volcanic eruptions. 


\section{Introduction}

The subduction of the Antarctic plate ( 49-53 $\left.{ }^{\circ} \mathrm{S}\right)$ and the Scotia Microplate $\left(\sim 53-55{ }^{\circ} \mathrm{S}\right)$ beneath the South American continent induces volcanism in the Andean mountain range between 49 and $55{ }^{\circ} \mathrm{S}$, referred to as the Austral Volcanic Zone (AVZ; Stern 2008). The volcanoes Lautaro and Fueguino represent the northern and southernmost volcanoes, respectively, of six known active volcanoes in the AVZ (Fig. 1A; Stern 2008). Late Glacial and Holocene eruption histories of the volcanoes in the AVZ have been reconstructed mainly using tephra layers deposited in soil outcrops, lake sediments, or peat sections (Kilian et al. 2003; Markgraf et al., 2003; Naranjo and Stern 2004; Stern 2004, 2008; Weller et al. 2015, 2017; Del Carlo et al. 2018). Explosive eruptions of the AVZ have also been reconstructed into the last glacial using long lake records from Laguna Potrok Aike $\left(51.97^{\circ} \mathrm{S} 70.38^{\circ} \mathrm{W}\right.$; Haberzettl et al. 2009; Wastegård et al. 2013).

Far less is known about more recent, historical volcanic events in the AVZ. In particular, there is a considerable gap in knowledge regarding the historical volcanic frequency of centres in the northern Austral Volcanic Zone (NAVZ) which includes Lautaro, Viedma and Aguilera volcanoes (Stern and Kilian 1996; Stern 2008; Fontjin et al. 2014). This is partly because of their location, which is difficult to reach, and generally ice-covered. Despite reports of historical eruptions (Lliboutry 1998; Martinic et al. 2008), hardly any traces of them have been found so far in natural archives (Fontjin et al. 2014). The identification of tephras in natural archives could confirm historical reports and provide information about the explosivity of these eruptions from the thickness and spatial distribution of the units. Moreover, previous geochemical fingerprints of NAVZ volcanoes (Stern and Kilian 1996; Stern 2008) are predominantly based on bulk tephra chemistry instead of more accurate single grain glass-shard geochemistry which was has only been rarely applied (Kastner et al. 2010). Closing this knowledge gap by studying lake sediment records and the individual glass shard tephra chemistry of the tephras in the vicinity of these volcanoes was the first major aim of our study. Our second major aim was to establish the effect of historical volcanic deposition on these lake ecosystems by analysing the palaeoenvironmental proxies of their natural sediment archives. The influence of volcanic ash fall on lake ecosystems has been debated in terms of changing $\mathrm{pH}$, habitat, and nutrient availability (Lotter et al. 1995; Telford et al. 2004; Self et al. 2015). Such short-term disturbance of lacustrine systems by volcanic eruptions can be manifested in biological and geochemical sedimentary proxies, but have only rarely been documented for southernmost South America. A regional example is given by the Lago Galletue (Chile) sediment record, where a shift in diatom and chironomid assemblages and a decreasing organic matter content was observed for a tephra ascribed to an eruption of Llaima volcano (Cruces et al. 2006; Urrutia et al. 2007).

Our study was conducted in the NAVZ. The research area is close to the eastern margin of the Southern Patagonian Ice Field (SPI), and east of the Andean mountain ridge with Mt. Fitz Roy (3406 m a.s.1.) being one of the most renowned regional mountain peaks (Fig. 1B). The persistent southern 
hemisphere westerlies dominate the climate and provoke a strong humidity gradient on the leeside of the Andes where the study sites are located (Garreaud et al. 2013). This precipitation gradient is reflected in the vegetation distribution, with a dense Nothofagus forest in the west and Patagonian steppe to the east (Fig 1A, B). The influence of this humidity gradient on lacustrine habitats is of interest for ongoing palaeolimnological studies. Additionally, the downwind position of lakes with respect to active volcanoes is beneficial for reconstructing eruption histories, as tephra is transported toward the sites. Despite this, the eruption history of NAVZ centres is still uncertain because of the remoteness of the area. After exploration of several regional lakes, the sediments of two small lakes, Laguna Gemelas Este (49.3849 $\mathrm{S} 72.8985^{\circ} \mathrm{W}, 880 \mathrm{~m}$ a.s.1.) and Laguna Verde (49.2090 $\mathrm{S} 72.9728^{\circ} \mathrm{W}, 560 \mathrm{~m}$ a.s.1.) were investigated in detail. Their mesoclimatic setting differs, but both contain continuous fine-grained sediment records with sufficient organic matter facilitating investigations of tephra layers and the effects of volcanic ash falls on Patagonian lake ecosystems.

The area surrounding the lakes partly belongs to the national park Los Glaciares. It was scarcely populated by indigenous people before European settlers arrived in the early $20^{\text {th }}$ century (Madsen 1952). Construction of El Chaltén, the only village in the investigated area, began in AD 1985 (Blanco 2003). Due to the remoteness and late settlement, reports about regional environmental trends and volcanic eruptions prior to that time are scarce. Although active volcanoes exist in that region, tephra records containing historical events are not yet established mainly due to the inaccessibility of volcanic cones and a lack of identified sediment records (Fontjin et al. 2014). An exception to this is the 2000year long sediment record from Lago del Desierto (Fig. 1B), in which a tephra layer was ascribed to the AD 1959/60 eruption of Lautaro volcano on the basis of chronology (Kastner et al. 2010). Moreover, tephra layers of unknown age were reported from regional soils and attributed to Lautaro, Hudson and Monte Burney volcanoes (Villegas et al. 2009). The area is also of great interest for palaeoclimatic and paleoenvironmental reconstructions. Evidence of recent climate change is given by accelerated shrinking of the SPI and adjacent glaciers documented using tree-ring analyses, moraine dating, and remote sensing (Masiokas et al. 2009; Meier et al. 2018).

Our study is a first step to overcome the lack of limnogeological and volcanological data for the historical past in the NAVZ. The glass-shard chemical composition and age of tephra deposits in short sediment cores from Lagunas Verde and Gemelas Este were investigated and a first attempt was made to attribute them to historical eruptions. The two lakes are comparable in size and morphometry but located at two ends of a humidity gradient in the Nothofagus forest. Thus, results also provide insights into the behaviour of lake systems under different hydroclimatic conditions and of the reaction of their nutrient cycles and diatom communities to short-term disturbances such as volcanic events.

\section{Materials and methods}

Sampling and scanning 
145 Sediment cores were recovered in April 2017 from a rubber boat with a percussion corer (Aquatic 146 Research Instruments, USA) from 5.8 and $5.0 \mathrm{~m}$ water depth at Laguna Verde and Laguna Gemelas 147 Este, respectively. Limnological parameters ( $\mathrm{pH}$, electric conductivity, water temperature) of lake 148 surface waters were analysed in the field with a Universal Pocket Meter (Multi 340i, WTW). The surface 149 of the recovered sediment cores was fixed with floral foam, the tubes were capped, and transported to the lab where they were cut lengthwise. Sediment core GEM17-1 from Laguna Gemelas Este had a core length of $37 \mathrm{~cm}$, and sediment core VER17-1 from Laguna Verde had a core length of $84 \mathrm{~cm}$. The smoothened surface of one core half was scanned and photographed with a X-ray-fluorescence (XRF)core scanner (ITRAX, Cox Analytics) equipped with a Mo-tube. Elemental contents are given in counts per second (cps) and were divided by coherence (coh) for standardisation (Hahn et al. 2014). Colour and lithological variations were described before the cores were subsampled in one-cm steps according to standard procedures (Ohlendorf et al. 2011). Volumetric samples $\left(11.9 \mathrm{~cm}^{3}\right)$ were weighed prior and after lyophilisation to obtain water content and bulk dry density (BDD) used for calculation of cumulative bulk dry mass. Sediment colours were determined with the Munsell soil colour chart on the fresh, non-oxidised sediment surface after core opening (Munsell Color 2000).

Bulk organic isotope-geochemistry

162

Lyophilised samples were carefully homogenised with a spatula and sieved at $250 \mu \mathrm{m}$ to obtain the fine sediment fraction free of larger organic and minerogenic particles. An amount of the fine sediment fraction to provide about $30 \mu \mathrm{g}$ of nitrogen (typically 3-40 mg dry matter) was weighed into tin capsules for total nitrogen content (TN, in wt. \%) and total nitrogen isotope $\left(\delta^{15} \mathrm{~N}_{\mathrm{TN}}\right)$ determinations. Likewise, an amount of the fine sediment fraction providing about $100 \mu \mathrm{g}$ of organic carbon (typically 1-20 mg dry matter) was weighed in tin capsules for total organic carbon content (TOC, in wt. \%) and organic carbon isotope $\left(\delta^{13} \mathrm{C}_{\mathrm{TOC}}\right)$ analyses. These samples were decalcified by acid fumigation with $32 \% \mathrm{HCl}$ for 16 hours in an empty desiccator (Harris et al. 2001) before folding and analysis. The packed samples were combusted at $1080{ }^{\circ} \mathrm{C}$ in an elemental analyser (EuroEA, Eurovector) with automated sample supply linked to an isotope-ratio-mass spectrometer (Isoprime, Micromass). Peak integration was used to determine TN and TOC contents and for calibration against elemental standards. The TOC/TN ratio is given as molar ratio. All isotope results are reported in \%o in the common $\delta$ notation according to the equation

$176 \delta=\left(\mathrm{R}_{\text {sample }} / \mathrm{R}_{\text {standard }}-1\right) \cdot 1000$ where $\mathrm{R}$ is the isotope ratio $\left({ }^{13} \mathrm{C} /{ }^{12} \mathrm{C},{ }^{15} \mathrm{~N} /{ }^{14} \mathrm{~N}\right)$ of the sample and an international standard (VPDB for carbon, AIR for nitrogen), respectively. Calibrated laboratory standards were used to ensure the quality of analyses and to relate the raw values to the isotopic reference scales. Albeit $\delta^{15} \mathrm{~N}_{\mathrm{TN}}$ measurements of 
Laguna Verde tephra layers had to be conducted near the detection limit of the instrument, no signs of disturbance were recorded in the respective chromatographs and values were reproducible.

\section{Radiometric dating}

Activities of ${ }^{137} \mathrm{Cs},{ }^{40} \mathrm{~K},{ }^{210} \mathrm{~Pb}$, and ${ }^{226} \mathrm{Ra}$ were determined gamma-spectrometrically with a High-PurityGermanium-Well Detector. Excess ${ }^{210} \mathrm{~Pb}$ data was obtained by subtracting ${ }^{226} \mathrm{Ra}$ from ${ }^{210} \mathrm{~Pb}$ activities (Appleby 2001). A constant-flux-constant-sedimentation (CFCS) model was used for ${ }^{210} \mathrm{~Pb}$ age determination (Sanchez-Cabeza and Ruiz-Fernández 2012). To approach the requirements for the CFCS model, all $1-\mathrm{cm}$ thick slices containing tephra layers were removed prior to age calculations. Additionally, negative and zero ${ }^{210} \mathrm{~Pb}$ activities were excluded for the age models and one and two outliers, respectively, at the bases of both records were discarded. The ${ }^{210} \mathrm{~Pb}$ activity at the sediment surface $\left(\mathrm{C}_{0}\right)$, the age and dry-mass-sedimentation rates were determined from linear regression of logarithmised excess ${ }^{210} \mathrm{~Pb}$ versus cumulative bulk dry mass using a half-life for ${ }^{210} \mathrm{~Pb}$ of 22.23 years (Sanchez-Cabeza and Ruiz-Fernández 2012). Lower and upper age estimates were determined from the sediment samples neighbouring the tephra layers, maximum and minimum errors were calculated by considering the slope error obtained in the aforementioned linear regression. Decay-corrected ${ }^{137} \mathrm{Cs}$ activities were calculated using a half-life of 30.07 years (Ribeiro Guevara and Arribére 2002).

\section{Compositional analysis of tephra deposits}

Tephra layers were identified visually, based on Ca peaks of XRF scans and on BDD anomalies. Tephra samples were wet sieved using demineralised water and a $25 \mu \mathrm{m}$ nylon mesh to reduce the presence of very fine-grained material inappropriate for chemical analysis. The remaining sample was oven dried at $50{ }^{\circ} \mathrm{C}$ and mounted in a multi-hole resin disc using SpeciFix-20 Epoxy resin (Froggatt and Gosson 1982). Once set, ground and polished, the disc was coated in carbon for chemical analysis (Lowe 2011). The major elemental properties of individual glass-shards in the sample were analysed at the Research Laboratory for Archaeology and the History of Art, University of Oxford using a wavelengthdispersive JEOL JXA-8600 electron microprobe (EMP), equipped with four spectrometers. Where the abundance of glass-shards was sufficient, thirty glass-shards were analysed for each sample. All analyses were conducted with a $6 \mathrm{nA}$ beam current, $15 \mathrm{kV}$ accelerating voltage and a $10 \mu \mathrm{m}$ beam diameter. To minimise element loss, sodium was analysed first. Elemental peaks were collected for 30 seconds (s), except for $\mathrm{Na}(12 \mathrm{~s}), \mathrm{P}(60 \mathrm{~s}), \mathrm{Cl}(50)$ and $\mathrm{Mn}$ (40 s), and for half of the total peak time on the background, either side of the peak. The machine was calibrated for each element using primary standards (minerals) prior to analysis. Also, to verify the calibration, Max Planck Institute (MPI-DING) reference glasses were analysed at the beginning, middle and end of analytical runs (StHs6-80/G, ATHO-G, GOR132-G); the averaged values of these are within 2 standard deviations of the preferred 
values as is standard (Jochum et al. 2006). During analysis, minerals, vesicles, and resin were avoided. To account for secondary hydration, data was normalised to $100 \mathrm{wt} \%$.

Diatom analyses

An aliquot of each sample was dried at $80{ }^{\circ} \mathrm{C}$, then oxidized with $\mathrm{H}_{2} \mathrm{O}_{2}(30 \mathrm{vol} \%)$ and heated in a microwave oven for 2 minutes, in order to eliminate organic material (Battarbee 1986). When removal of clay from the sediments was necessary, the samples were also treated following Bates et al. (1978). Samples were then rinsed repeatedly until neutrality with distilled water. Permanent slides were mounted using Naphrax ${ }^{\circledR}$. A minimum of 400 valves per slide were counted in order to calculate relative abundances in percent and numbers of individuals per gram of dry sediment. Observations were made using a Reichert-Jung Polivar binocular optical microscope equipped with an immersion objective (Plan Apo 100X, NA 1.32) and differential interference contrast optics. For identification of diatom taxa, the works of Frenguelli (1923, 1942), Metzeltin and Lange-Bertalot (1998, 2007), Rumrich et al. (2000), and Metzeltin et al. (2005) were used.

\section{Results}

Sites and limnology

Laguna Verde is located in a humid forest with approximately $930 \mathrm{~mm}$ average annual precipitation (Estancia Huemules meteorological station, period 2007-2016, $1.4 \mathrm{~km} \mathrm{SE}$ of the lake; Fig. 1C). The lake has an area of $0.029 \mathrm{~km}^{2}$, is fed by a small inflowing creek, and is located in a basin surrounded by dense forest of Nothofagus pumilio. The catchment area is mountainous and has slope angles up to $40^{\circ}$ on the western side of the lake. The lake's maximum diameter is $305 \mathrm{~m}$ and its maximum water depth $5.8 \mathrm{~m}$. It is surrounded by bulrush (Schoenoplectus sp.) and hosts few aquatic macrophytes (Potamogeton sp., aquatic mosses). During three visits in April $(2015,2017,2018)$ electric conductivities of $20-30 \mu \mathrm{S} \mathrm{cm}^{-}$ ${ }^{1}, \mathrm{pH}$ values of 6.8-7.4 and temperatures of 5.2-10.2 ${ }^{\circ} \mathrm{C}$ were measured in the surface water.

Laguna Gemelas Este is located just above the lower tree line, which is $1 \mathrm{~km}$ west of the lake. The lower tree line is at an altitude of 550-650 $\mathrm{m}$ a.s.1. and caused by insufficient rainfall for tree growth. A meteorological station in the steppe close to the lower tree line and $5.4 \mathrm{~km}$ NNE from the lake receives about $305 \mathrm{~mm}$ average annual precipitation (Río de las Vueltas meteorological station, period 1993-2016, Fig. 1C). The name Lagunas Gemelas ("twin lakes" in Spanish) refers to two adjacent lakes, a shallow western and a deeper eastern lake. Here we report data from the eastern lake referred to as Laguna Gemelas Este. It has no surficial inflow, an area of $0.04 \mathrm{~km}^{2}$, a maximum diameter of $310 \mathrm{~m}$, a maximum depth of $5.2 \mathrm{~m}$, and is surrounded by a patchy forest of Nothofagus pumilio close to the steppe-forest ecotone. A few aquatic macrophytes (aquatic mosses, Isoetes sp., Myriophyllum sp.) grow 
inside the lake. Surface water had electric conductivities of $16-20 \mu \mathrm{S} \mathrm{cm}^{-1}, \mathrm{pH}$ values of 7.2-7.7 and temperatures of $3.2-7.9{ }^{\circ} \mathrm{C}$ measured in April of the years 2015-2018.

Sedimentology and bulk-sediment geochemistry

In cores from both lakes, macroscopically visible tephra layers are characterized by high Ca contents (given as $\mathrm{Ca} \mathrm{coh}^{-1}$ ), high BDD, and low contents of TOC and TN (Fig. 2 A, B). Tephra layers showing these characteristics occurred at 4-5 cm, 10-15 cm, 17-22 cm and below $36 \mathrm{~cm}$ in GEM17-1. Ca contents are missing for the latter tephra at the core base because of analytical reasons, but a high BDD value indicates it clearly, as does visual identification (Fig. 2A). Similarly, tephras were detected at 5-11 cm, $16-18 \mathrm{~cm}, 20-28 \mathrm{~cm}$, and 54-58 cm in VER17-1. The four tephras of GEM17-1 were labelled GT1-GT4 from top to bottom, the four of VER17-1 were labelled VT1-VT4.

Sediment core GEM17-1 from Laguna Gemelas Este consists of brownish-grey (Munsell colours $2.5 \mathrm{Y} 5 / 3,2.5 \mathrm{Y} 4 / 3,2.5 \mathrm{Y} 4 / 2$ ), organic-rich mud intercalated by the silty-to-sandy, greyish (2.5Y7/1) tephra layers (Fig. 2A). The upper part of GEM17-1 has high TOC (4-13 wt. \%) and TN (0.3-1.3 wt. \%) contents outside of tephra layers and can be classified as diatomaceous biogenic mud. The lower part (>32 cm depth) contains less TOC and TN, possibly due to a higher admixture of minerogenic components. The dark colour of a layer at $27-28 \mathrm{~cm}$ also appears to be of minerogenic and not of organic origin as TOC and TN are not increasing. TOC/TN ratios generally vary between 6 and 24 with an exceptionally high TOC/TN ratio of 54 at $30.5 \mathrm{~cm}$ depth. $\delta^{13} \mathrm{C}_{\mathrm{TOC}}$ values range between -22 and $-18 \%$ and $\delta^{15} \mathrm{~N}_{\mathrm{TN}}$ between 1 and $4 \%$. During deposition of tephras GT1 and GT3, but not GT2, the carbon isotopic composition changes. The $\delta^{13} \mathrm{C}_{\text {TOC }}$ values are up to $2.6 \%$ lower in GT3 and $1.6 \%$ higher in GT1 than in sediment surrounding the tephra.

Sediment core VER17-1 from Laguna Verde consists of laminated, clayey, olive-grey mud (5Y4/2, $5 \mathrm{Y} 5 / 2,5 \mathrm{Y} 6 / 2)$ intercalated by four greyish to violet-greyish (5Y6/1, 7.5YR6/2), sandy tephras (Fig. 2B). Outside of the tephra layers, VER17-1 exhibited overall lower TOC (1.1-8.0 wt. \%) and TN contents (0.1-1.1 wt. \%) than GEM17-1. TOC/TN ratios range from 6-24. Highest TOC/TN values were reached at the base of VT3 and between VT2 and VT1. The latter peak is coincident with a TOC maximum. A second TOC maximum occurs immediately above VT4, this time coinciding with a TN maximum, increased $\delta^{13} \mathrm{C}_{\mathrm{TOC}}$ values and a blackish layer. $\delta^{15} \mathrm{~N}_{\mathrm{TN}}$ values decrease up to $5.2 \%$ in each tephra layer compared to tephra-free sections exhibiting $\delta^{15} \mathrm{~N}_{\mathrm{TN}}$ values between -0.5 and $2.0 \%$.

\section{Radiometric dating and tephra stratigraphy}

\footnotetext{
${ }^{137} \mathrm{Cs}$ data exhibit a double peak in GEM17-1 at $1.5\left(82.0 \mathrm{~Bq} \mathrm{~kg}^{-1}\right)$ and $5.5 \mathrm{~cm}\left(69.2 \mathrm{~Bq} \mathrm{~kg}^{-1}\right)$ while ${ }^{210} \mathrm{~Pb}$
} activities show a distinct minimum centred at $3-5 \mathrm{~cm}$ sediment depth, coeval with the low ${ }^{137} \mathrm{Cs}$ inbetween the two peaks (Fig. 3A). The ${ }^{137} \mathrm{Cs}$ and ${ }^{210} \mathrm{~Pb}$ minima are related to the thin tephra layer GT1 
diluting the radioisotopes. In contrast to GEM17-1, the ${ }^{137} \mathrm{Cs}$ record of VER17-1 exhibits only one single peak with a maximum at 2-3 cm sediment depth and a steady exponential decrease of ${ }^{210} \mathrm{~Pb}$ between 0 and $5 \mathrm{~cm}$ depth (Fig. 3B), suggesting that GT1 has no counterpart in VER17-1.

The lake records were dated using excess ${ }^{210} \mathrm{~Pb}$. At first, tephra layers were removed for calculation of cumulative dry mass leading to the result of steadily increasing values with depth (Fig. 3). Exponential regressions (CFCS model) resulted in mean dry-mass-sedimentation rates of $51 \mathrm{mg} \mathrm{cm}^{-}$ ${ }^{2} \mathrm{a}^{-1}\left(\mathrm{R}^{2}=0.85\right)$ and $34 \mathrm{mg} \mathrm{cm}^{-2} \mathrm{a}^{-1}\left(\mathrm{R}^{2}=0.91\right)$ and extrapolated $\mathrm{C}_{0}$ values of $168 \mathrm{~Bq} \mathrm{~kg}^{-1}$ and $171 \mathrm{~Bq} \mathrm{~kg}^{-1}$ for GEM17-1 and VER17-1, respectively.

The ${ }^{210} \mathrm{~Pb}$ chronologies allow estimations of the timing of tephra deposition. For GEM17-1, the resulting age ranges were AD 1986-1998 for GT1, AD 1943-1968 for GT2, AD 1927-1955 for GT3, and AD 1849-1892 for GT4 including the given error ranges (Fig. 3A). The age ranges of VER17-1 were AD 1940-1970 for VT1, AD 1888-1934 for VT2, and AD 1871-1920 for VT3 (Fig. 3B). VT4 is outside of the dated depth range due to the short half-life of ${ }^{210} \mathrm{~Pb}$. An attempt to extrapolate its age using the exponential regression obtained from the CFCS model resulted in an estimated deposition age of AD 1536-1669.

Geochemical composition of tephra deposits

The geochemical properties of seven tephra layers (GT1, GT2, GT3, and VT1, VT2, VT3, VT4) were analysed. GT4 was not analysed, because of little available material. The analysis of glass was made difficult by the high abundance of minerals. VT1 was noted as being a particularly mineral-poor sample in comparison to other analysed samples and was characterised by a greater abundance of colourless cuspate and fluted glass-shards. There is no remarkable compositional difference between all tephra layers (Table 1; Fig. 4). All identified tephra deposits are rhyolitic and the major elemental glass-shard chemistry suggests a similar eruptive source. Across all samples, the average silica content is $75.30 \pm$ 1.08 wt. $\%$. The average potassium concentration is $3.37 \pm 0.23 \mathrm{wt} . \%$, and the averaged calcium and titanium content is $1.87 \pm 0.43 \mathrm{wt} \% \%$ and $0.30 \pm 0.08 \mathrm{wt}$ \% , respectively (Table 1 ).

\section{Diatoms}

For sediment core GEM17-1, diatom assemblages of all samples were analysed except for three (16-17, 21-22 and 24-25 cm) without enough material for analyses. Overall, the diatoms were well preserved, and exhibited a maximum concentration of $7010^{6}$ valves $\mathrm{g}^{-1}$ of dry sediment at 7-8 $\mathrm{cm}$ depth (Fig. 5A). The total abundance is highly variable, with frequently lower concentrations if volcanic eruptions occurred. Lowest concentrations were found in the samples prior to and at the base of GT2. Only one planktonic/tychoplanktonic taxon, Aulacoseira sp. 1, was found and its relative abundance fluctuates strongly in the record. The taxon is most abundant in the samples between GT3 and GT4. Minimum 
values of Aulacoseira sp. 1 occur in the upper part of the core but do not always coincide with the tephra layers. The most abundant benthic/epiphytic taxa were Psamothidium marginulatum, Encyonema sileciacum, Nitzschia fonticola, Pinnularia aff. appendiculata, Sellaphora tridentula, Sellaphora sp. 1, Staurosirella sp. 12 and Staurosirella sp. 8. Some benthic/epiphytic taxa, such as Psamothidium marginulatum, Pinnularia aff. appendiculata, and Sellaphora tridentula show relative abundance peaks within one or more tephra layers. Nitzschia fonticola reaches continuously high relative abundances after the deposition of GT3. (Fig. 5A).

The VER17-1 sediment core has an overall high diatom concentration, except when tephra layers are present. Lowest diatom abundances occurred in the tephra layers VT1-VT4. The innermost part of tephra VT1 $(8-9 \mathrm{~cm}$ of the tephra located between 5 and $11 \mathrm{~cm})$ did not contain any diatoms. Diatom concentration reaches its maximum value at $32 \mathrm{~cm}$ depth $\left(410 \cdot 10^{6}\right.$ valves $\mathrm{g}^{-1}$ of dry sediment $)$ and decreases again below. This sediment core is characterised by dominance of two Aulacoseira species (Aulacoseira sp. 1 and sp. 2), that occur in relatively high relative abundances over the whole sequence, except for tephra layers where they almost disappear, leading to short periods with dominance of benthic/epiphytic diatoms such as Encyonema silesiacum, Nitzschia frustulum var. minutula, small fragilarioids, Sellaphora sp. 1 and Tabellaria flocculosa (Fig. 5B).

\section{Discussion}

Regional history of explosive volcanic eruptions

The analysis of volcanic ash layers identified in the AVZ are often limited to bulk chemistry (e.g., Stern, 2008; Weller et al., 2015, 2017). This is problematic because bulk chemical analysis can be influenced by the abundance of minerals present in the sample. It is therefore preferable to utilise individual-grain glass-shard analysis to correlate between records (e.g., Fontijn et al., 2016; Del Carlo et al., 2018). There is, however, limited comparative chemical data due to the remote and often ice-covered locations of AVZ centres (and particularly NAVZ centres) and the lack of glass-shard analyses.

AVZ deposits are rich in silica, but have variable potassium as a consequence of magma variations along the volcanic arc, and as such potassium is a useful indicator of their source (Kilian et al., 2003). For example, the widespread $\mathrm{R}_{1}$ unit from Reclus volcano has an average $\mathrm{SiO}_{2}$ and $\mathrm{K}_{2} \mathrm{O}$ content of $77.60 \mathrm{wt} \%$ and $2.60 \mathrm{wt} \%$ of its glass, respectively (Del Carlo et al., 2018). Comparatively, the widespread MB1 unit from Mt Burney volcano has a slightly higher average $\mathrm{SiO}_{2}$ and slightly lower average $\mathrm{K}_{2} \mathrm{O}$ content of $78.31 \mathrm{wt} \%$ and $2.01 \mathrm{wt} \%$ of its glass, respectively (Del Carlo et al., 2018). The $\mathrm{A}_{1}$ unit from Aguilera volcano has an average $\mathrm{SiO}_{2}$ and $\mathrm{K}_{2} \mathrm{O}$ content of $75.81 \mathrm{wt} \%$ and $4.14 \mathrm{wt} \%$ of its glass, respectively (Stern, 2008). By comparison, bulk tephra and pumice analyses of the same $A_{1}$ unit provide a much lower $\mathrm{SiO}_{2}$ and $\mathrm{K}_{2} \mathrm{O}$ content of $65.34 \mathrm{wt} \%$ and $2.26 \mathrm{wt} \%$, respectively (Stern, 2008). Analysis of glass in deposits attributed to Lautaro volcano indicates a $\mathrm{SiO}_{2}$ and $\mathrm{K}_{2} \mathrm{O}$ content of $\sim 75 \mathrm{wt} \%$ 
and $\sim 3.3 \mathrm{wt} \%$, respectively (Kastner et al., 2010), while bulk chemical analysis points toward a lower $\mathrm{SiO}_{2}$ and $\mathrm{K}_{2} \mathrm{O}$ content of $65.72 \mathrm{wt} \%$ and $2.05 \mathrm{wt} \%$, respectively (Motoki et al., 2006). The pumice analysed in the bulk sample is reported to contain minerals such as hornblende and orthopyroxene (Motoki et al., 2006), which may have altered the analyses when compared to glass data by Kastner et al. (2010). There is no chemical data (bulk or glass-shard) for tephra from Viedma volcano available yet.

The geochemical signature of all tephra layers investigated in this study is similar and, thus, indicates the same eruptive source. With respect to tephras identified from AVZ volcanoes like Monte Burney, Reclus and Aguilera (Stern 2008), the samples in GEM17-1 and VER17-1 have an intermediate potassium concentration (average across all samples is $3.4 \mathrm{wt}$ \%). The chemical composition of volcanic deposits is in-line with NAVZ deposits as identified by Stern (2008) and Del Carlo et al. (2018). The closest volcanoes with known historical activity are Lautaro, Viedma, and possibly Aguilera (Fig. 1A, B; references within Fontjin et al. 2014). The geochemical signatures of tephra layers investigated here are congruent with those of pure glass shards from the Lago del Desierto sediment record, where a tephra was tentatively ascribed to the 1959/60 eruption of Lautaro (Kastner et al. 2010). It is, however, important to note that i) the compositional fields of Austral Volcanic Zone volcanic centres are still relatively ill-defined, ii) there is no glass-chemical data for Viedma volcano which is nearby to Lautaro volcano, iii) the high abundance of minerals in the investigated tephras resulted in a low number of chemical analyses, and iv) there is still chronological uncertainty for this historical period. As such, an assignment of these layers to a historical eruptive age based on the major elemental glass-shard chemistry alone cannot be accomplished yet.

The chemical affinity of the deposits identified from Lagunas Gemelas Este and Verde follow a similar compositional trend to that of Aguilera volcano, but with a slightly lower potassium content (Stern 2008). As no comparable glass-shard chemistry of tephras from Lautaro, Viedma and Aguilera volcanoes for comparison exist, the assignment of these tephras in our records is mainly based on geographical and chronological reasoning. It is hypothesised that all but one of the tephra deposits identified for Lagunas Gemelas Este and Verde sedimentary sequences originate from Lautaro volcano, due to the following reasons: Firstly, Lautaro volcano is closer to the coring locations than any other AVZ volcano, except for Viedma volcano. Secondly, Lautaro has been the most frequently erupting NAVZ volcano in the region during the recent past (Lliboutry 1998; Motoki et al. 2006; Martinic 2008; Siebert et al. 2010; Fontijn et al. 2014) and is at $42 \mathrm{~km} \mathrm{WNW}$ and $60 \mathrm{~km}$ WNW distance from Laguna Verde and Laguna Gemelas Este, respectively. As winds in this area frequently have a (north-)westerly direction (Garreaud et al. 2009), tephra of Lautaro's eruptions will very likely arrive in the area of investigation. Several confirmed eruptions have been reported from Lautaro volcano at: AD 1978/79, 1972, 1959-60, 1945, 1933, 1883, 1878/79, and 1876 (details and references in Table 2). The only known historical eruption of Viedma volcano was in AD 1988 (Kilian 1990; Siebert et al. 2010). One other historical eruption occurred in AD 1886. Burmeister (1891) described widespread ash fall in the 
Santa Cruz valley and other areas in Patagonia in that year, pointing to an eruption of one of the volcanoes in the NAVZ at that time. Fontjin et al. (2014; supplementary data, erroneously dated to AD 1891 there) attributed this eruption to Aguilera, but any other NAVZ volcano is also possible. The independently dated Laguna Gemelas Este and Laguna Verde sequences indicate that the timing of the tephra units best fits to the reported historical eruptions of Lautaro. These factors strongly suggest that Lautaro volcano is the main source of tephra layers identified in Laguna Gemelas Este and Laguna Verde, except for GT1 (Fig. 6). GT1 proffers the main source of uncertainty because the ${ }^{210} \mathrm{~Pb}$ and ${ }^{137} \mathrm{Cs}$ chronologies disagree at this point in the sequence.

${ }^{137} \mathrm{Cs}$ is exclusively related to anthropogenic radioactive fallout in the course of atmospheric nuclear weapon tests and nuclear accidents. Globally significant ${ }^{137} \mathrm{Cs}$ fallout started in AD 1954, reached a first maximum in AD 1959-1960, and an absolute maximum in AD 1963-1964 (Appleby 2001). In Argentina, however, maximum fallout occurred in AD 1964-1966, while peaks in AD 19701972 and AD 1974 were related to tropospheric fallout from south Pacific atmospheric nuclear weapon testings (Ribeiro Guevara and Arribére 2002). The bimodal ${ }^{137} \mathrm{Cs}$ distribution in GEM17-1 suggests that GT1 diluted the ${ }^{137} \mathrm{Cs}$ peak. Thus, the ash fall happened around or after maximum ${ }^{137} \mathrm{Cs}$ deposition, i.e. around the 1960-70's or later. ${ }^{210} \mathrm{~Pb}$ gives a more precise date for the deposition of GT1 and relates it to the 1990's. The absence of this thin tephra layer in the ${ }^{137} \mathrm{Cs}$ record of Laguna Verde might be explained by the position of this lake outside of the fallout lobe of that specific eruption. As no major eruption was reported from Lautaro volcano in the 1990's, the tephra most likely originates from the eruption of Viedma volcano in 1988, which is $28 \mathrm{~km}$ to the west of the lake (Fig. 1B). Equally, the ${ }^{210} \mathrm{~Pb}$ dating may be inaccurate at this point in the sequence, and the ${ }^{137} \mathrm{Cs}$ may be more appropriate; in this case, the deposit would likely be from the Lautaro eruption of $1978 / 79$, because the decay-corrected ${ }^{137} \mathrm{Cs}$ nonetheless indicates a post-maximum fallout date for GT1 (Fig. 3A).

The similar ${ }^{210} \mathrm{~Pb}$ age ranges of GT2 and VT1 imply that they very likely represent the same eruptive event that happened between the 1940's and 1970's. ${ }^{210} \mathrm{~Pb}$ ages of VT2 and GT3 are less clearly corresponding in age, pointing to the same or two different eruptions in the first half of the last century. Finally, VT3 is ${ }^{210} \mathrm{~Pb}$ dated to the ending of the $19^{\text {th }}$ or the beginning of the $20^{\text {th }}$ century. Albeit their assignment to Lautaro volcano is preliminary, these tephra records to the best of our knowledge represent the first evidences of frequent and widespread eruptions of this volcano in recently deposited lake sediments. ${ }^{210} \mathrm{~Pb}$ chronologies give age ranges for tephra deposition of GT2-4 and VT1-3 fitting to historical dates, but cannot provide accurate, annually resolved ages for single tephra layers. Among the historical eruptions reported so far, the most likely candidates to match our sedimentary tephra deposits due to their elevated volcanic explosivity indices (VEI; Newhall and Self 1982) are the Lautaro eruptions of AD 1959-60 (GT2, VT1), AD 1933 (GT3, VT2), and AD 1876 or 1878/79 (GT4, VT3) (Table 2; Fig. 6). The eruptions of AD 1883 from Lautaro volcano (Martinic 2016) or the eruption of AD 1886 (Burmeister 1891) from an unidentified volcano in the NAVZ may also be possible candidates for the tephras deposited around the end of the $19^{\text {th }}$ century (Table 2; Fig. 6). 
440 Impact of volcanic eruptions (tephra deposition) and hydroclimate on lake ecosystems

After volcanic eruptions, volcanic ash can be remobilised by wind erosion over several years in Patagonia (Wilson et al., 2011). Therefore, organic matter and biogenic particles contained in the tephra layers could represent not only the immediate time of eruption (weeks and months), but in the extreme also several years thereafter.

The influence of volcanic eruptions and tephra deposition varied between both investigated lakes. No clear organic-geochemical changes common to all tephra layers were observed in GEM17-1. In contrast, $\delta^{15} \mathrm{~N}_{\mathrm{TN}}$ shifted to $2.1 \%$ lower values, on average, in the tephra layers of VER17-1 compared to normal sedimentation (Fig. 7) while neither TOC/TN nor $\delta^{13} \mathrm{C}_{\mathrm{TOC}}$ show comparable shifts (Fig. 2). Since the TOC and TN content of tephra layers is lower in VER17-1 compared to GEM17-1, any impact of the tephras may also be more likely to be visible in VER17-1. As the shift is evident mainly in the nitrogen isotope ratios, the input of allochthonous organic matter with isotopically low $\delta^{15} \mathrm{~N}$ values during volcanic eruptions can be excluded as explanation for the $\delta^{15} \mathrm{~N}_{\mathrm{TN}}$ shifts in VER17-1. Rather, increased loads of allochthonous organic nitrogen from terrestrial plant sources may lead to increased TOC/TN ratios (Meyers and Lallier-Vergés 1999), but this is not observed for the tephra layers of VER17-1. Deposition of higher amounts of soil organic matter, with comparatively low TOC/TN ratios in Patagonia (11-17; Mayr et al. 2009), during ash falls can also be excluded, as Patagonian soils have comparatively high $\delta^{15} \mathrm{~N}$ signatures (2-9 \%; Mayr et al. 2009). The most likely explanation therefore is a disturbance of the lacustrine nitrogen cycle provoked by each eruption and lasting for the duration of the specific eruption (weeks to months). Massively increased turbidity during volcanic activity due to ash fallout could have led to light limitation and decreased nitrogen assimilation in the lacustrine ecosystem (Finlay and Kendall 2007). Lower nitrogen consumption by primary producers, such as diatoms, leads to more negative $\delta^{15} \mathrm{~N}$ values of their biomass due to less nitrate utilization (Waser et al. 1998). As the organic matter content, however, is generally very low in the tephra layers, the low $\delta^{15} \mathrm{~N}$ values therein more likely originate from inorganic nitrogen. Inorganic nitrogen potentially was more frequently available due to the reduced primary production and was then bound as ammonium to the minerogenic fraction of the tephra.

Diatom assemblages show repeated breakdowns of planktonic/tychoplanktonic communities during tephra deposition. This was more evident in Laguna Verde than in Laguna Gemelas Este (Fig. $5 \mathrm{~A}, \mathrm{~B})$. As for species composition in both assemblages, the one from Laguna Verde was completely dominated by Aulacoseira spp. except for the tephra layers, while in Laguna Gemelas Este there were different species with shifting importance along the core. Outside of tephra layers, the diatom assemblage from Laguna Verde is dominated by the planktonic/tychoplanktonic Aulacoseira spp. This genus has highly silicified valves and forms thread-like colonies that require high water turbulence in order to remain suspended in the photic zone of the lake (Fernandez et al. 2013; Recasens et al. 2015). 
A decrease of Aulacoseira spp. only occurs during tephra deposition in VER17-1, denoting its sensibility to volcanic ash fall. Ash fall could have increased turbidity in the water column, causing increased light attenuation and reduction of the depth of the photic zone. This would largely diminish the development of planktonic/tychoplanktonic taxa while the non-planktonic taxa were less hampered by light limited conditions.

In Laguna Gemelas Este, epiphytic/benthic diatoms frequently dominated and there is higher variability between planktonic/tychoplanktonic species and epiphytic/benthic ones. Diatoms have shown their sensitivity to tephra impacts, such as water turbidity, altered habitats, changing water chemistry and nutrient availability through changing their total abundance and/or assemblage composition (Barker et al 2000; Egan et al 2018). However, lake systems are variable and complex, being affected by a much wider range of factors (Telford et al. 2004). A clear link of changes in the diatom record to tephra deposition, as it seems to be the case for Laguna Verde, is less clear in GEM171 and only obvious for GT2-GT4 and not for GT1 (Fig. 5A). The less clear pattern in GEM17-1 is mainly due to a generally higher variability between planktonic/tychoplanktonic species versus epiphytic/benthic diatoms at Laguna Gemelas Este than at Laguna Verde. This higher variability can be explained by additional factors than tephra deposition. Firstly, the samples with minimum occurrence of Aulacoseira sp. 1 may be related to a lake level-low stand, as a lower water level confines their (tycho)planktonic habitat and enlarges benthic habitats. Secondly, Fey et al. (2009) suggested for the Patagonian Laguna Las Vizcachas that a higher amount of epiphytic taxa could point to stronger windinduced lateral water movements by dragging littoral diatoms from their habitat to the lake centre. Thirdly, in contrast to the point mentioned before, less intense wind-induced turbulence could also disadvantage Aulacoseira in comparison to benthic/epiphytic taxa as the taxon is favoured by windinduced lake turbulence (Giles et al. 2018). In summary, the potential factors influencing diatom assemblages are more complex at Laguna Gemelas Este than at Laguna Verde, possibly due to the fact that it is situated in a much more wind-exposed topographical position compared to Laguna Verde.

Effects of volcanic eruptions are possibly also less pronounced in the GEM17-1 record due to a more distal position in the fallout lobe indicated by finer-grained and thinner tephra layers than those identified in VER17-1. An additional cause for less tephra having entered Laguna Gemelas Este may have been the less humid climate and the flatter relief compared to Laguna Verde. The inclination of the slopes adjacent to the west of Laguna Verde is $27^{\circ}$ on average and can reach extreme values of more than $40^{\circ}$, whereas Laguna Gemelas Este is located on a hillock with a slope of less than $2^{\circ}$. Thus, tephra eroded by surface runoff more easily enters Laguna Verde than Laguna Gemelas Este, the more so as the latter has no surficial inflow in contrast to the former.

Different hydrologic settings may have had an effect on the absolute isotope values of the two sediment records as well. At the drier Laguna Gemelas Este site, $\delta^{13} \mathrm{C}_{\mathrm{TOC}}$ and $\delta^{15} \mathrm{~N}_{\mathrm{TN}}$ was, on average, $5.2 \%$ and $1.3 \%$ higher, respectively, than at the more humid site, Laguna Verde (when tephra deposits are excluded). Surface sediments from 72 lakes along a climatic gradient in western Chile showed a 
significant increase of $\delta^{13} \mathrm{C}_{\mathrm{TOC}}$ and $\delta^{15} \mathrm{~N}_{\mathrm{TN}}$ with decreasing mean annual precipitation (Contreras et al. 2018). The causes for such humidity-dependent absolute isotope differences could be manifold, including varying ratios of allochthonous-to-autochthonous organic matter and variations in nutrient fluxes (Mayr et al. 2009; Fan et al. 2017; Contreras et al. 2018) and cannot be disentangled without better knowledge of carbon and nitrogen cycles of the specific lakes.

\section{Conclusions}

This study is a first step towards detecting and analysing tephras of historic volcanic eruptions from Lautaro volcano, and eventually also Viedma volcano, with an ultimate goal to better understand the potential impacts of volcanic ash on lake ecosystems in the area of El Chaltén. Our first findings show that Lautaro tephras are regionally widespread and can be used as time markers once the tephrochronological framework is completed. We could also demonstrate that the effects of ash fall can vary markedly between lake ecosystems in similar distance to the volcanic centre, probably depending on different limnological conditions imposed by the respective mesoclimatic and geomorphological settings. Ongoing studies will shed further light on the regional distribution of observed tephras and improve their tephrochronological values by studying additional lake sites and proxy parameters. This data is, and will be, of significance to understanding the eruptive history of AVZ centres, and the environmental impacts volcanic events can have.

\section{Acknowledgements}

CM and JM acknowledge funding by BMBF (01DN16025) and cooperation project BMBF/MINCYT (AL15/03). RES is funded by NERC as part of the Environmental Research Doctoral Training Partnership at the University of Oxford (grant: NE/L002621/1). We are indebted to Ana Srur for help in the field and Sabine Stahl for assistance with XRF scanning. We thank the National Park Los Glaciares for support and permission of sampling. The provision of local meteorological data by the Argentinian Undersecretary of Water Resources of the Nation, Federico Reese, and Valeria Luvisoti is gratefully acknowledged. We are grateful to Sebastien Bertrand, an anonymous reviewer, and the editors for comments on an earlier version of the manuscript.

\section{References}

Appleby PG (2001) Chronostratigraphic techniques in recent sediments. In: Last WM, Smol JP (eds) Tracking environmental change using lake sediments, Volume I: Basin analysis, coring and chronological techniques. Kluwer Academic Publishers, Dordrecht, pp 171-203 
Barker P, Telford R, Merdaci O, Williamson D, Taieb M, Vincens A, Gibert E (2000) The sensitivity of a Tanzanian crater lake to catastrophic tephra input and four millennia of climate change. The Holocene 10:303-310

Bates CD, Coxon P, Gibbard PL (1978) A new method for the preparation of clay-rich sediment samples for palynological investigation. New Phytol 81:459-463

Battarbee RW (1986) Diatom Analysis. In: Berglund BE (ed) Handbook of Holocene Palaeoecology and Palaeohydrology. J Wiley \& Sons Ltd., New York, pp 527-570

Blanco E (2003) El Chaltén, un desafío al pie de la cordillera de Los Andes. Tiempos Patagónicos 9

Burmeister CV (1891) Breves datos sobre una excursión a Patagonia. Rev Museo de la Plata 2:381-394

Contreras S, Werne JP, Araneda A, Urrutia R, Conejero CA (2018) Organic matter geochemical signatures (TOC, TN, $\mathrm{C} / \mathrm{N}$ ratio, $\delta^{13} \mathrm{C}$ and $\delta^{15} \mathrm{~N}$ ) of surface sediment from lakes distributed along a climatological gradient on the western side of the southern Andes. Sci Total Environ 630:878 888

Cruces F, Urrutia R, Parra O, Araneda A, Treutler H, Bertrand S, Fagel N, Torres L, Barra R, Chirinos L (2006) Changes in diatom assemblages in an Andean lake in response to a recent volcanic event. Arch Hydrobiol 165:23-35

Del Carlo P, Di Roberto A, D’Orazio M, Petrelli M, Angioletti A, Zanchetta G, Maggi V, Daga R, Nazzari M, Rocchi S (2018) Late Glacial-Holocene tephra from southern Patagonia and Tierra del Fuego (Argentina, Chile): A complete textural and geochemical fingerprinting for distal correlations in the Southern Hemisphere. Quat Sci Rev 195:153-170

Egan J, Allot THE, Blackford JJ (2018) Diatom-inferred aquatic impacts of the mid-Holocene eruption of Mount Mazama, Oregon, USA. Quat Res 1-16. doi:10.1017/qua.2018.73

Fan J, Xiao J, Wen R, Zhang S, Wang X, Cui L, Yamagata H (2017) Carbon and nitrogen signatures of sedimentary organic matter from Dali Lake in Inner Mongolia: Implications for Holocene hydrological and ecological variations in the East Asian summer monsoon margin. Quat Int 452:65-78

Fernández M, Björck S, Wohlfarth B, Maidana NI, Unkel I, Van der Putten N (2013) Diatom assemblage changes in lacustrine sediments from Isla de los Estados, southernmost South Amerika, in response to shifts in the southwesterly wind belt during last deglaciation. J Paleolimnol 50:433446

Fey M, Korr C, Maidana NI, Carrevedo ML, Corbella H, Dietrich S, Haberzettl T, Kuhn G, Lücke A, Mayr C, Ohlendorf C, Paez MM, Quintana FA, Schäbitz F, Zolitschka B (2009) Palaeoenvironmental changes during the last 1600 years inferred from the sediment record of a cirque lake in southern Patagonia (Laguna Las Vizcachas, Argentina). Palaeogeogr Palaeoclimatol Palaeoecol 281:363-375 
Finlay JC, Kendall C (2007) Stable isotope tracing of temporal and spatial variability in organic matter sources to freshwater ecosystems. In: Michener R, Lajtha K (eds) Stable Isotopes in Ecology and Environmental Science. Blackwell, Malden, pp 283-333

Fontjin K, Lachowycz SM, Rawson H, Pyle DM, Mather TA, Naranjo JA, Moreno-Roa H (2014) Late Quaternary tephrostratigraphy of southern Chile and Argentina. Quat Sci Rev 89:70-84

Frenguelli J (1923) Contribuciones para la sinopsis de las diatomeas argentinas. I Diatomeas del Río Primero en la ciudad de Córdoba. Boletín de la Academia Nacional de Ciencias de Córdoba 27:13-119.

Frenguelli J (1942) Xvii Contribución al conocimiento de las diatomeas argentinas. Diatomeas del Neuquén (Patagonia). Revista del Museo de La Plata (n.s.) 5 Botánica 20:73-219.

Froggatt PC, Gosson GJ (1982) Techniques for the preparation of tephra samples for mineral and chemical analysis and radiometric dating. Department of Geology, Victoria University of Wellington, 23:1-2

Garreaud RD, Vuille M, Compagnucci R, Marengo J (2009) Present-day South American climate. Palaeogeogr Palaeoclimatol Palaeoecol 281:180-195.

Garreaud R, Lopez P, Minvielle M, Rojas M (2013) Large-Scale Control on the Patagonian Climate. J Climate 26:215-230

Giles MP, Michelutti N, Grooms C, Smaol JP (2018) Long-term limnological changes in the Ecuadorian páramo: Comparing the ecological responses to climate warming of shallow waterbodies versus deep lakes. Freshwater Biol 63:1316-1325.

Global Volcanism Program (2013) Volcanoes of the World, v. 4.7.4. Venzke E (ed) Smithsonian Institution. Downloaded 29 Oct 2018. https://doi.org/10.5479/si.GVP.VOTW4-2013

Haberzettl T, Anselmetti FS, Bowen SW, Fey M, Mayr C, Zolitschka B, Ariztegui D, Mauz B, Ohlendorf C, Kastner S, Lücke A, Schäbitz F, Wille M (2009) Late Pleistocene dust deposition in the Patagonian steppe - extending and refining the paleoenvironmental and tephrochronological record from Laguna Potrok Aike back to 55 ka. Quat Sci Rev 28:29272939

Hahn A, Kliem P, Oehlerich M, Ohlendorf C, Zolitschka B, the PASADO Science Team (2014) Elemental composition of the Laguna Potrok Aike sediment sequence reveals paleoclimatic changes over the past 51 ka in southern Patagonia, Argentina. J Paleolimnol 52:349-366

Hansen, MC, Potapov, PV, Moore R, Hancher M, Turubanova SA, Tyukavina A, Thau D, Stehman SV, Goetz SJ, Loveland TR, Kommareddy A, Egorov A, Chini L, Justice CO, Townshend JRG (2013) High-Resolution Global Maps of 21st-Century Forest Cover Change. Science 15:850853

Harris D, Horwáth WR, van Kessel C (2001) Acid fumigation of soils to remove carbonates prior to total organic carbon or CARBON-13 isotopic analysis. Soil Sci Soc Am J 65:1853-1856 
Jochum KP, Stoll B, Herwig K, Willbold M, Hofmann AW, Amini M, Aarburg S, Abouchami W, Hellebrand E, Mocek B, Raczek I, Stracke A, Alard O, Bouman C, Becker S, Dücking M, Brätz H, Klemd R, De Bruin D, Canil D, Cornell D, De Hoog CJ, Dalpé C, Danyushevshy L, Eisenhauer A, Gao Y, Snow JE, Groschopf N, Günther D, Latkoczy C, Guillong M, Hauri EH, Höfer HE, Lahaye Y, Horz K, Jacob DE, Kasemann SA, Kent AJR., Ludwig T, Zack T, Mason PRD, Meixner A, Rosner M, Misawa K, Nash BP, Pfänder J, Premo WR, Sun WD, Tiepolo M, Vannucci R, Vennemann T, Wayne D, Woodhead JD (2006) MPI-DING reference glasses for in situ microanalysis: New reference values for element concentrations and isotope ratios. Geochem Geophys Geosyst 7, Q02008, doi:10.1029/2005GC001060

Kastner S, Enters D, Ohlendorf C, Haberzettl T, Kuhn G, Lücke A, Mayr C, Reyss J-L, Wastegård S, Zolitschka B (2010) Reconstructing 2000 years of hydrological variation derived from laminated proglacial sediments of Lago del Desierto at the eastern margin of the Southern Patagonian Ice Field, Argentina. Global Planet Change 72:201-214

Kilian R (1990) The Australandean Volcanic Zone (South Patagonia). In: Symposium international "Géodynamique andine": Résumés des communication, Grenoble, France. Orstom, Paris: 301304

Kilian R, Hohner M, Biester H, Wallrabe-Adams HJ, Stern CR (2003) Holocene peat and lake sediment tephra record from the southernmost Chilean Andes (53-55 ${ }^{\circ}$ ). Rev Geol Chile 30:23-37.

Lliboutry L (1998) Glaciers of the Wet Andes. In: Williams J, Ferringo R (eds) Glaciers of South America. US Geological Survey Professional Paper 1386-I, pp 148-206

Lotter AE, Birks HJB, Zolitschka B (1995) Late-glacial pollen and diatom changes in response to two different environmental perturbations: volcanic eruption and Younger Dryas cooling. $\mathrm{J}$ Paleolimnol 14: 23-47

Lowe DJ (2011). Tephrochronology and its application: A review. Quat Geochronol 6:107-153.

Madsen A (1952) Patagonia vieja. Ciordia y Rodríguez, Buenos Aires

Markgraf V, Bradbury JP, Schwalb A, Burns SJ, Stern C, Ariztegui D, Anselmetti FS, Stine S, Maidana N (2003) Holocene palaeoclimates of southern Patagonia: limnological and environmental history of Lago Cardiel, Argentina. The Holocene 13:597-607

Martinic M (1988) Actividad volcánica histórica en la region de Magallanes. Rev Geol Chile 15:181186

Martinic M (2008) Registro historico de antecedentes volcánicos y sísmicos en la Patagonia Austral y la Tierra del Fuego. Magallania 36:5-18

Martinic M (2016) La erupción del volcán de los gigantes (Lautaro) en 1883. Algunas Consideraciones. Magallania 44:65-68

Masiokas M, Rivera A, Espizua LE, Villalba R, Delgado S, Aravena JC (2009) Glacier fluctuations in extratropical South America during the past 1000 years. Palaeogeogr Palaeoclimatol Palaeoecol 281:242-268 
Mayr C, Lücke A, Maidana NI, Wille M, Haberzettl T, Corbella H, Ohlendorf C, Schäbitz F, Fey M, Janssen S, Zolitschka B (2009) Isotopic fingerprints on lacustrine organic matter from Laguna Potrok Aike (southern Patagonia, Argentina) reflect environmental changes during the last 16,000 years. J Paleolimnol 42:81-102

Meier WJ-H, Grießinger J, Hochreuther P, Braun MH (2018) An updated multi-temporal glacier inventory for the Patagonian Andes with changes between the Little Ice Age and 2016. Front Earth Sci 6, doi: 10.3389/feart.2018.00062

Messager ML, Lehner B, Grill G, Nedeva I, Schmitt O (2016) Estimating the volume and age of water stored in global lakes using a geo-statistical approach. Nat Commun 7, 13603, doi: $10.1038 /$ ncomms 13603

Meyers P, Lallier-Vergés E (1999) Lacustrine sedimentary organic matter records of late Quaternary paleoclimates. J Paleolimnol 21:345-372

Metzeltin D, Lange-Bertalot H (1998) Tropical diatoms of South America I. About 700 predominantly rarely known or new taxa representative of the neotropical flora. Iconogr Diatomol 5:1-695

Metzeltin D, Lange-Bertalot H (2007) Tropical diatoms of South America II. Special remarks on biogeographic disjunction. Iconogr Diatomol 18:1-877

Metzeltin D, Lange-Bertalot H, García-Rodríguez F (2005) Diatoms of Uruguay. Compared with other taxa from South America and elsewhere. Iconogr Diatomol 15:1-736

Motoki A, Orihashi Y, Naranjo J, Hirata D, Skvarca P, Anma R (2006) Geologic reconnaissance of Lautaro Volcano, Chilean Patagonia. Rev Geol Chile 33:177-187

Munsell Color (2000) Munsell Soil Color Charts. Grand Rapids, USA

Naranjo JA, Stern CR (2004) Holocene tephrochronology of the southernmost part $\left(42^{\circ} 30^{\prime}-45^{\circ} \mathrm{S}\right)$ of the Andean Southern Volcanic Zone. Rev Geol Chile 31:224-240

Ohlendorf C, Gebhardt C, Hahn A, Kliem P, Zolitschka B, the PASADO science team (2011) The PASADO core processing strategy - A proposed new protocol for sediment core treatment in multidisciplinary lake drilling projects. Sediment Geol 239:104-115

Recasens C, Ariztegui D, Maidana NI, Zolitschka B, The PASADO Science Team (2015) Diatoms as indicators of hydrological and climatic changes in Laguna Potrok Aike (Patagonia) since the Late Pleistocene. Palaeogeogr Palaeoclimatol Palaeoecol 417:309-319

Ribeiro Guevara S, Arribére M (2002) ${ }^{137}$ Cs dating of lake cores form the Nahuel Huapi National Park, Patagonia, Argentina: Historical records and profile measurements. J Radioanal Nucl Ch 252:37-45

Rumrich U, Lange-Bertalot H, Rumrich M (2000) Diatoms of the Andes. From Venezuela to Patagonia/Tierra del Fuego. Iconogr Diatomol 9:1-649

Sanchez-Cabeza JA, Ruiz-Fernández AC (2012) ${ }^{210} \mathrm{~Pb}$ sediment radiochronology: An integrated formulation and classification of dating models. Geochim Cosmochim Acta 82:183-200 
Self AE, Klimaschewski A, Solovieva N, Jones VJ, Andrén E, Andreev AA, Hammarlund D, Brooks SJ (2015) The relative influences of climate and volcanic activity on Holocene lake development inferred from a mountain lake in central Kamchatka. Global Planet Change $134: 67-81$

Siebert L, Simkin T, Kimberly P (2010) Volcanoes of the world. Smithsonian Institution, Berkeley/Los Angeles

Stern C (1990) Tephrochronology of Southernmost Patagonia. Natl Geogr Res 6:110-126

Stern CR (2004) Active Andean volcanism: its geologic and tectonic setting. Rev Geol Chile 31:1-51

Stern C (2008) Holocene tephrochronology record of large explosive eruptions in the southernmost Patagonian Andes. Bull Volcanol 70:435-454

Stern CR, Kilian R (1996) Role of the subducted slab, mantle wedge and continental crust in the generation of adakites from the Andean Austral Volcanic Zone. Contrib Mineral Petrol $123: 263-281$

Telford RJ, Barker, P, Metcalfe S, Newton A. (2004) Lacustrine responses to tephra deposition: examples from Mexico. Quat Sci Rev 23:2337-2353

Urrutia R, Araneda A, Cruces F, Torres L, Chirinos L, Treutler HC, Fagel N, Bertrand S, Alvial I, Barra $\mathrm{R}$, Chapron E (2007) Changes in diatom, pollen, and chironomid assemblages in response to a recent volcanic event in Lake Galletue (Chilean Andes). Limnologica 37:49-62

Villegas DC, Pereyra FX, Viaggio M, Ferrer JA (2009) Occurencia de materiales piroclásticos en suelos de tres sectores del oeste de Santa Cruz. Revista de la Asociación Geológica Argentina 64:303311

Waser NAD, Harrison PJ, Nielsen B, Calvert SE, Turpin DH (1998) Nitrogen isotope fractionation during the uptake and assimilation of nitrate, nitrite, ammonium, and urea by a marine diatom. Limnol Oceanogr 43:215-224

Wastegård S, Veres D, Kliem P, Hahn A, Ohlendorf C, Zolitschka B, The PASADO Science Team (2013) Towards a late Quaternary tephrochronological framework for the southernmost part of South America - the Laguna Potrok Aike tephra record. Quat Sci Rev 71:81-90

Weller DJ, Miranda CG, Moreno PI, Villa-Martínez R, Stern CR (2015). Tephrochronology of the southernmost Andean Southern Volcanic Zone, Chile. Bull Volcanol 77:1-24

Weller DJ, de Porras ME, Maldonado A (2017). Holocene tephrochronology of the lower Río Cisnes valley, southern Chile. Andean Geol 44:229-248

Wilson TM, Cole JW, Stewart C, Cronin SJ, Johnston DM (2011) Ash storms: impacts of windremobilised volcanic ash on rural communities and agriculture following the 1991 Hudson eruption, southern Patagonia, Chile. Bull Volcanol 73:223-239 


\section{Figure captions}

729

Fig. 1 (A) Map of southern South America showing the research area (box) and major active volcanoes: Cerro Hudson (CH), Arenales (AR), Lautaro (L), Viedma (V), Aguilera (AG), Reclús (R), Monte Burney (MB), Fueguino (F). The extension of the Austral Volcanic zone (AFZ) and northern Austral Volcanic Zone (NAVZ) is indicated. (B) Southern Patagonian Ice Field, subglacial Lautaro and Viedma volcanoes, and the research area next to El Chaltén. The forested area is given in green colour. (C) Position of Laguna Verde and Laguna Gemelas Este in the area around El Chaltén, crosses mark the meteorological stations at Estancia Huemules (EH) and Río de las Vueltas (RV). Base map: SRTM, LP DACC NASA Version 3, forested area: Hansen et al. (2013), water bodies: Messager et al. (2016), glaciated area: Meier et al. (2018)

Fig. 2 Geochemical and isotopic records and core photographs of GEM17-1 (A) and VER17-1 (B). Grey bars highlight tephra layers readily recognizable by their $\mathrm{Ca} / \mathrm{coh}$ records. Error bars of organic geochemical data represent standard deviations of 2-3 analyses.

Fig. 3 Cumulative dry mass, activities of ${ }^{137} \mathrm{Cs}$ (solid symbols: original data, open symbols: decaycorrected data), excess ${ }^{210} \mathrm{~Pb}$, and ${ }^{210} \mathrm{~Pb}$ ages of the upper $35 \mathrm{~cm}$ of GEM17-1 (A) and VER17-1 (B). Dates given represent mean ${ }^{210} \mathrm{~Pb}$ ages, bars represent maximum and minimum possible ages. Excess ${ }^{210} \mathrm{~Pb}$ values used for the age models are given with solid symbols. The maximum and minimum age ranges of tephra layers are shown as grey bars.

Fig. 4 Variation diagrams of glass-chemical data identified from tephra layers in GEM17-1 (GT1-3) and VER17-1 (VT1-4) sediment cores. Each data point represents one glass-shard analysis, for average chemical composition of tephras see Table 1.

Fig. 5 Assemblages of the most important diatom taxa (in percent), total diatom concentration (log scale) and percentage of benthic and epiphytic $(\mathrm{B}+\mathrm{E})$ versus planktonic and tychoplanktonic $(\mathrm{P}+\mathrm{T})$ diatom taxa of GEM17-1 (A) and VER17-1 (B). Only taxa are shown that occurred with an abundance $>5 \%$ in at least 2 samples.

Fig. 6 Schematic timeline of historical eruptive events of Lautaro, Viedma, and an eruption of an unidentified NAVZ volcano as recorded in the literature (Table 2) against tephra layers identified in Lagunas Verde (VT1-3) and Gemelas Este (GT1-4) which have been chronologically constrained using ${ }^{210} \mathrm{~Pb}$ measurements. Filled circles represent high-explosivity, open circles low-explosivity events. Ages are presented using the lower and upper age estimates by black bars, and maximum and minimum errors 
764 as grey lines. Vertical bars highlight the historical volcanic eruptions most likely present in the lacustrine 765 tephra records with a volcanic explosivity index (VEI) $\geq 2$.

766

767 Fig. $7 \delta^{15} \mathrm{~N}_{\mathrm{TN}}$ versus $\delta^{13} \mathrm{C}_{\mathrm{TOC}}$ values for GEM17-1 (A) and VER17-1 (B). Sediment layers containing 768 tephra (black circles) are optically distinguished from those without tephra (open circles). Only for 769 VER17-1 a different $\delta^{15} \mathrm{~N}_{\mathrm{TN}}$ signature is observed during tephra deposition. 

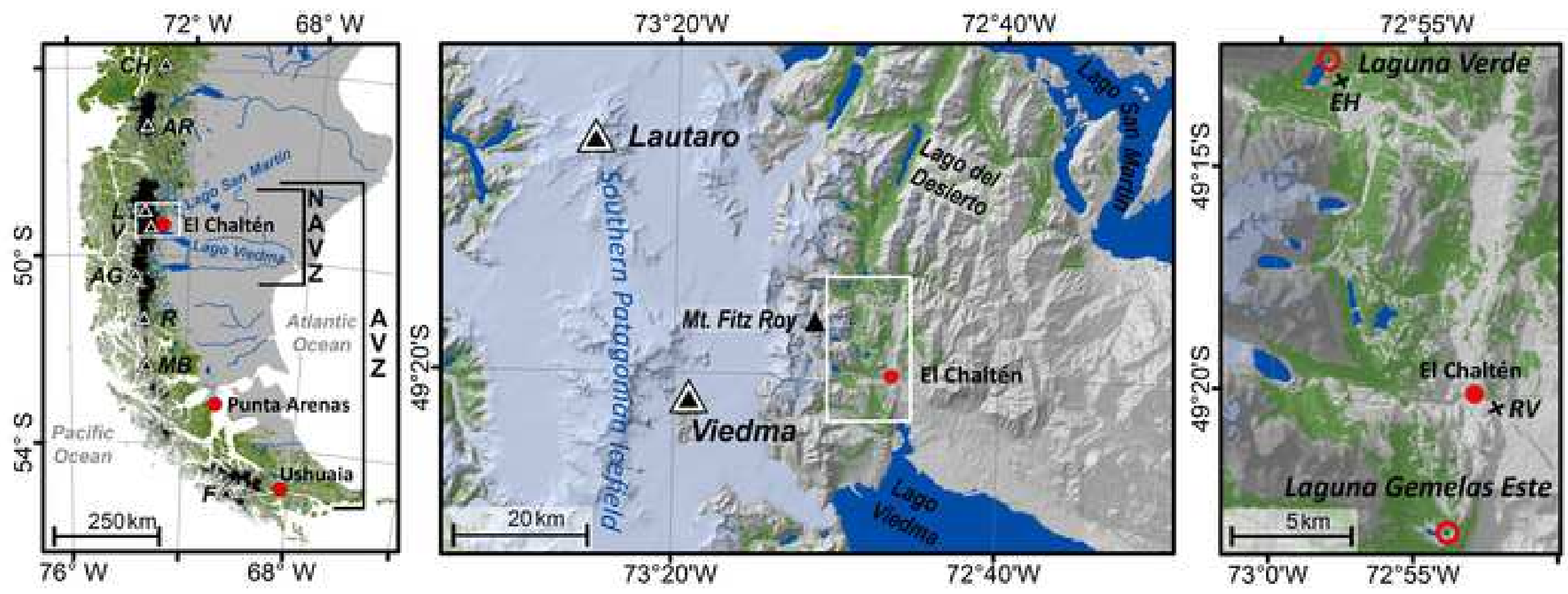
Click here to access/download;Figure;Fig.4.pdf $\underline{\underline{\underline{ }}}$
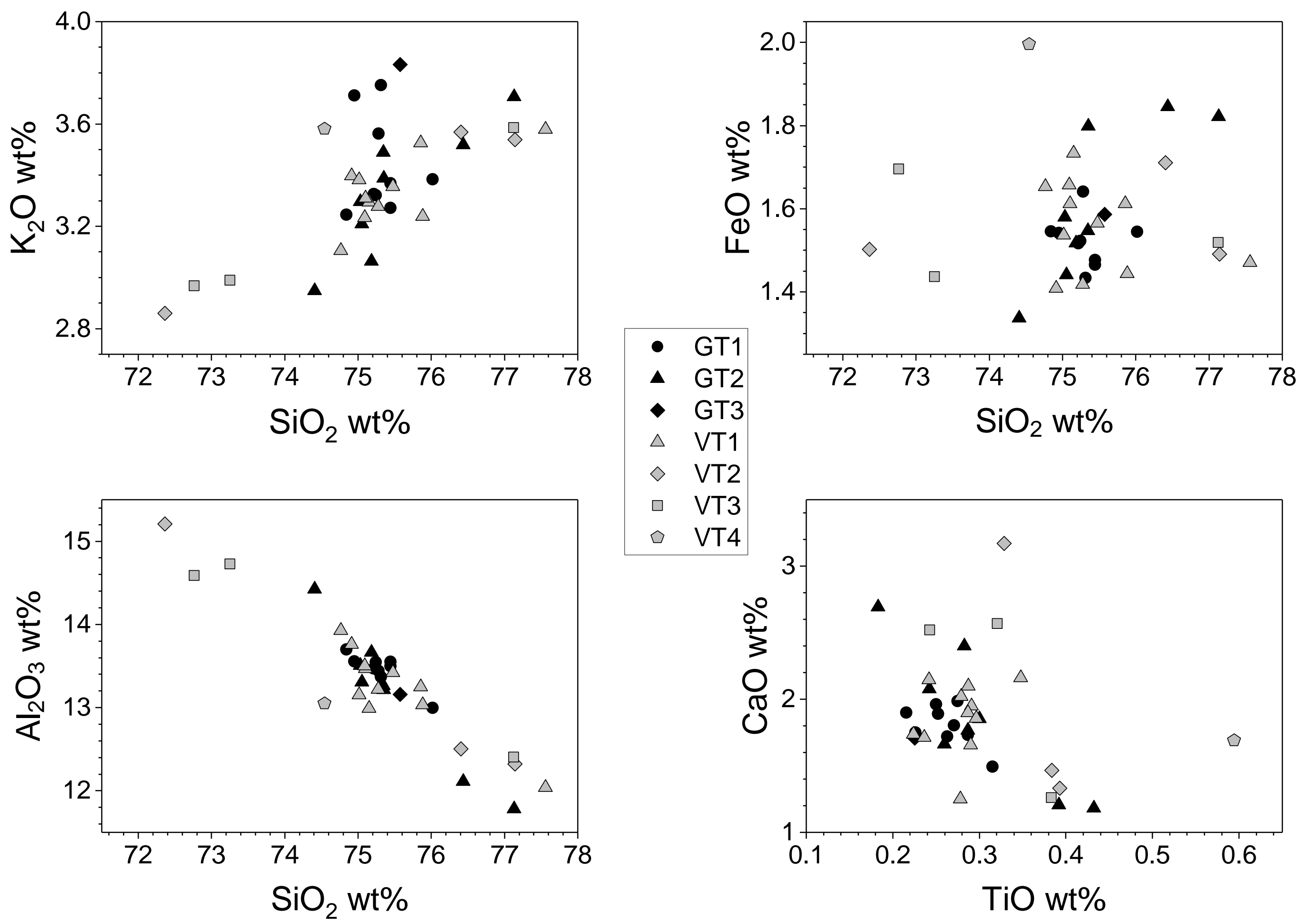

$\mathrm{TiO} w t \%$ 


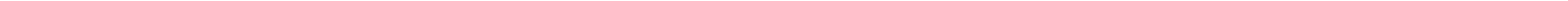




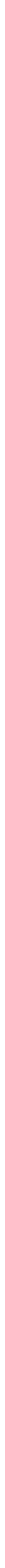




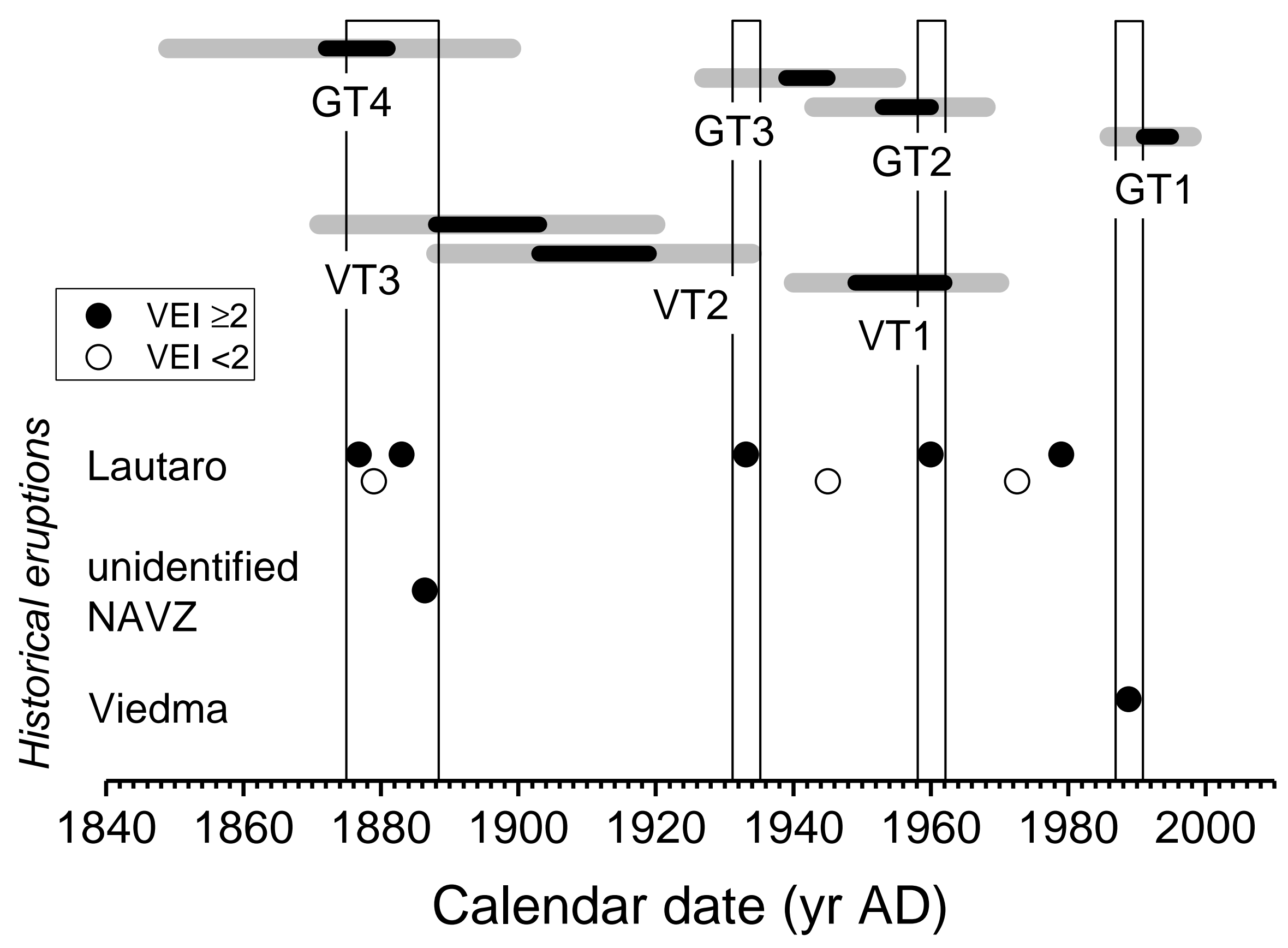


Table 1 Individual glass-shard major elemental composition (means and standard deviations) of seven tephras identified in GEM17-1 (GT1-3) and VER17-1 (VT1-4).

\begin{tabular}{|l|l|r|r|r|r|r|r|r|r|r|r|r|r|}
\hline Label & & $\mathrm{SiO}_{2}$ & $\mathrm{TiO}_{2}$ & $\mathrm{Al}_{2} \mathrm{O}_{3}$ & $\mathbf{F e O}$ & $\mathrm{MnO}$ & $\mathrm{MgO}$ & $\mathrm{CaO}$ & $\mathrm{Na}_{2} \mathrm{O}$ & $\mathrm{K}_{2} \mathrm{O}$ & $\mathrm{P}_{2} \mathrm{O}$ & $\mathrm{Cl}$ & Total \\
\hline GT1 & avg & 75.31 & 0.26 & 13.46 & 1.52 & 0.03 & 0.29 & 1.80 & 3.66 & 3.44 & 0.04 & 0.19 & 96.86 \\
\hline$n=9$ & sdev & 0.34 & 0.03 & 0.20 & 0.06 & 0.03 & 0.04 & 0.15 & 0.16 & 0.19 & 0.02 & 0.03 & 1.96 \\
\hline GT2 & avg & 75.49 & 0.30 & 13.16 & 1.61 & 0.03 & 0.28 & 1.86 & 3.70 & 3.33 & 0.07 & 0.18 & 97.48 \\
\hline$n=8$ & sdev & 0.87 & 0.08 & 0.85 & 0.19 & 0.04 & 0.06 & 0.53 & 0.15 & 0.25 & 0.04 & 0.02 & 1.52 \\
\hline GT3 & avg & 75.57 & 0.23 & 13.16 & 1.59 & 0.05 & 0.20 & 1.71 & 3.51 & 3.83 & 0.07 & 0.09 & 98.11 \\
\hline$n=1$ & & & & & & & & & & & & & \\
\hline VT1 & avg & 75.46 & 0.28 & 13.25 & 1.56 & 0.04 & 0.26 & 1.86 & 3.73 & 3.34 & 0.05 & 0.18 & 97.46 \\
\hline$n=11$ & sdev & 0.78 & 0.03 & 0.49 & 0.11 & 0.04 & 0.07 & 0.27 & 0.28 & 0.13 & 0.03 & 0.03 & 1.61 \\
\hline VT2 & avg & 75.30 & 0.37 & 13.35 & 1.57 & 0.03 & 0.19 & 1.99 & 3.68 & 3.32 & 0.05 & 0.15 & 96.94 \\
\hline$n=3$ & sdev & 2.57 & 0.03 & 1.62 & 0.12 & 0.03 & 0.05 & 1.03 & 0.44 & 0.40 & 0.05 & 0.02 & 1.15 \\
\hline VT3 & avg & 74.38 & 0.32 & 13.91 & 1.55 & 0.04 & 0.28 & 2.12 & 3.96 & 3.18 & 0.12 & 0.15 & 97.54 \\
\hline$n=3$ & sdev & 2.39 & 0.07 & 1.30 & 0.13 & 0.03 & 0.17 & 0.74 & 0.72 & 0.35 & 0.09 & 0.04 & 2.51 \\
\hline VT4 & avg & 74.55 & 0.59 & 13.05 & 2.00 & 0.00 & 0.40 & 1.69 & 3.92 & 3.58 & 0.16 & 0.06 & 98.92 \\
\hline$n=1$ & & & & & & & & & & & & & \\
\hline
\end{tabular}


Table 2 Historic eruptions in the NAVZ. VEI is obtained from Global Volcanism Program (2013), except for eruptions of 1883 and 1886, which were estimated from historic descriptions as referenced.

\begin{tabular}{cccl} 
Volcano & $\begin{array}{c}\text { Year of } \\
\text { eruption }\end{array}$ & VEI & \multicolumn{1}{c}{ Reference } \\
Viedma & 1988 & 2 & Kilian (1990) \\
Lautaro & $1978 / 79$ & 2 & Lliboutry (1998) \\
Lautaro & 1972 & 1 & Lliboutry (1998) \\
Lautaro & $1959 / 60$ & 2 & Martinic (1988) \\
Lautaro & 1945 & 1 & Lliboutry (1998) \\
Lautaro & 1933 & 2 & Martinic 1988 \\
Unidentified, & 1886 & $\geq 2$ & Burmeister (1891) \\
NAVZ & 1883 & $\geq 2$ & Martinic 2016 \\
Lautaro & $1878 / 79$ & $?$ & Martinic 2008 \\
Lautaro & 1876 & 2 & Martinic 1988 \\
Lautaro & & &
\end{tabular}

